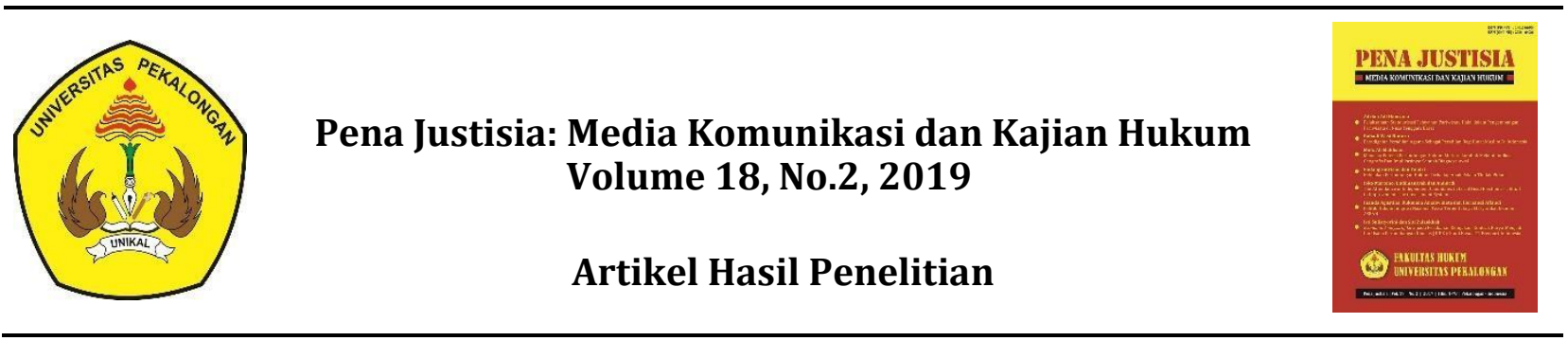

\title{
HAK MEREK SEBAGAI JAMINAN GADAI UNTUK PERMODALAN UMKM INDUSTRI KREATIF KERAJINAN BATIK
}

\author{
Miftahur Rahman Hakim $^{* *}$, Nur Kholidah ${ }^{* *}$ \\ ** STIE Muhammadiyah Pekalongan, Jawa Tengah, Indonesia. Email: miftahurrh@gmail.com \\ ** STIE Muhammadiyah Pekalongan, Jawa Tengah, Indonesia.
}

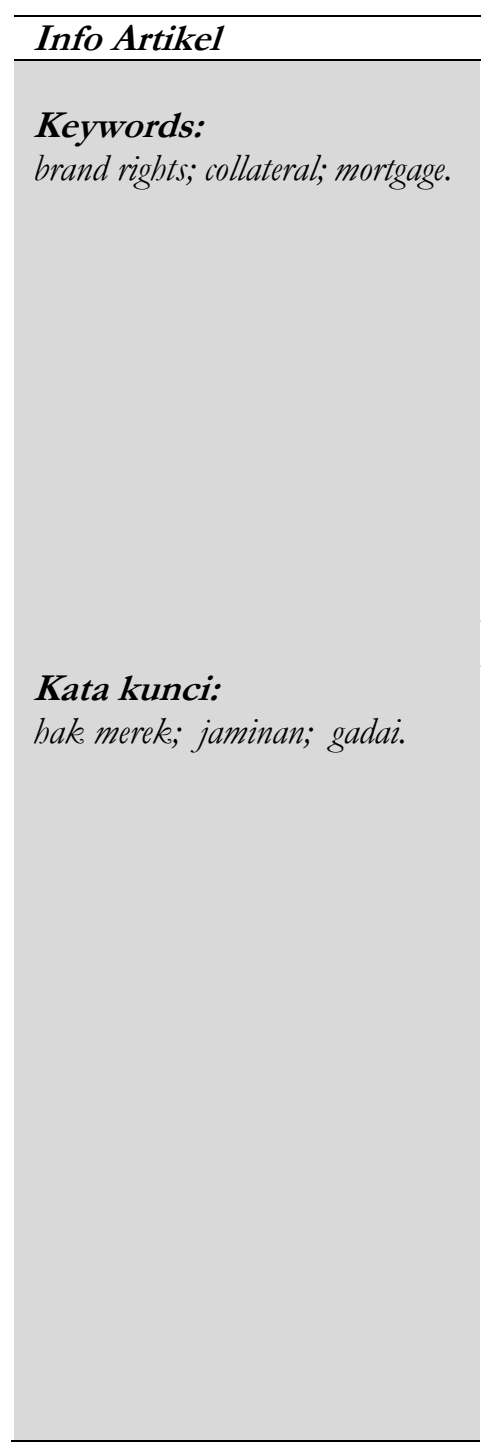

\begin{abstract}
Creative industries are industries that intensify information and creativity by relying on stock of knowledge and ideas from Human Resources (HR). One type of creative industry is the batike creative industry. Industrial development was hindered by the inability to access capital, whether provided by the government or other financial institutions. The purpose of this study was to initiate the utilization of batik industry brand rights as collateral for pawning. This type of research uses library research (library research) obtained from literature sources through library research. Then use descriptive methods. Data collection techniques in this study are document studies. Then the data analysis includes: Descriptive Analysis (Analysis Descriptive) and Content Analysis (Content Analysis). The results of the study show that brand rights can be used as collateral for pawning. The use of brand rights as collateral is expected to support the growth of the UMKM batik creative industries in Pekalongan.

\section{Abstrak}

Industri kreatif adalah industri yang mengintensifkan informasi dan kreativitas dengan mengandalkan stock of knowledge dan ide dari Sumber Daya Manusia (SDM). Salah satu jenis industri kreatif adalah industri kreatif batik. Perkembangan industri kreatif terhalang oleh kurang mampunya UMKM dalam mengakses permodalan baik yang disediakan oleh pemerintah ataupun lembaga keuangan lainnya. Tujuan dari penelitian ini adalah untuk memprakarsai pemanfaatan hak merek industri batik sebagai jaminan gadai. Jenis penelitian ini menggunkan penelitian pustaka (library Research) yang diperoleh dari sumber literatur melalui riset kepustakaan. Kemudian menggunakan metode deskriptif. Tehnik pengumpulan data dalam penelitian ini bersifat studi dokumen. Kemudian dilakukan analisis data meliputi: analisis deskriptif (Analysis Descriptive) dan analisis isi (Content Analysis). Hasil penelitian menunjukan bahwa hak merek dapat digunakan sebagai jaminan gadai. penggunaan hak merek sebagai jaminan ini diharapkan dapat mendukung pertumbuhan UMKM industri kreatif batik di Pekalongan.
\end{abstract}




\section{PENDAHULUAN}

Di era ekonomi sekarang telah lahir sebuah konsep ekonomi baru yakni konsep ekonomi kreatif yang mengintensifkan informasi dan kreativitas dengan mengandalkan stock of knowledge dan ide dari Sumber Daya Manusia (SDM) sebagai faktor produksi utama dalam kegiatan ekonominya. Struktur perekonomian dunia mengalami transformasi dengan cepat seiring dengan pertumbuhan ekonomi, dari yang tadinya berbasis Sumber Daya Alam (SDA) sekarang menjadi berbasis SDM, dari era pertanian ke era industri dan informasi. ${ }^{1}$

Ekonomi kreatif digerakkan oleh sektor industri yang disebut industri kreatif. Seperti disampaikan dalam Rencana Pengembangan Ekonomi Kreatif 2009-2015 yang dikeluarkan Departemen Perdagangan, definisi industri kreatif adalah Industri yang berasal dari pemanfaatan kreativitas, keterampilan serta bakat individu untuk menciptakan kesejahteraan serta lapangan pekerjaan melalui penciptaan dan pemanfaatan daya kreasi dan daya cipta individu tersebut. ${ }^{2}$

Perkembangan industri kreatif di Indonesia memberikan kontribusi yang cukup signifikan terhadap perekonomian dan penyerapan tenaga kerja, serta memiliki peranan penting dalam pemberdayaan SDM. Berdasarkan data statistik Kementerian Pariwisata dan Ekonomi Kreatif (Kemenparekraf) sepanjang tahun 2010-2013, kontribusi industri kreatif terhadap PDB diperkirakan sebesar 7,1\%, dan terhadap keseluruhan nilai ekspor sebesar 6,1\%, serta terhadap penyerapan tenaga kerja sebesar 10,7\%. Pertumbuhan industri kreatif adalah 5,6\% dengan sektor kerajinan, fesyen dan kuliner yang memiliki angka pertumbuhan tertinggi dibandingkan dengan sektor lainnya, yaitu: periklanan, arsitektur, pasar barang seni, desain, video-film-fotografi, permainan interaktif, musik, seni pertunjukan, penerbitan-percetakan, layanan komputer-piranti lunak, radio-televisi, dan riset-pengembangan. ${ }^{3}$

Melalui INPRES No. 6/2009 yang kemudian diikuti dengan terbitnya PP No. 92/2011, Pemerintah Indonesia telah menunjukkan perhatian dan komitmen untuk mengembangkan industri kreatif di Indonesia. Hal ini ditindaklanjuti dengan penyusunan Rencana Pengembangan Ekonomi Kreatif 2009-2015 dan Rencana Pengembangan 14 Sub sektor Industri Kreatif 20092015 oleh Kementerian Perdagangan, serta Rencana Strategis Pengembangan Industri Kreatif 2012-2014 oleh Kemenparekraf. ${ }^{4}$

Pengembangan indutri kreatif di Indonesia juga memiliki potensi dan tantangan. Kemenparekraf telah mengidentifikasi sedikitnya terdapat tujuh isu strategis yang menjadi potensi sekaligus tantangan yang perlu mendapatkan perhatian para pemangku kepentingan dalam pengembangan industri kreatif mendatang antara lain: Ketersediaan sumber daya kreatif yang profesional dan kompetitif; Ketersediaan sumber daya alam yang berkualitas, beragam, dan kompetitif; serta sumber daya budaya yang dapat diakses secara mudah; Industri kreatif yang berdaya saing, tumbuh, dan beragam; Ketersediaan pembiayaan yang sesuai, mudah diakses dan kompetitif; Perluasan pasar bagi karya kreatif; Ketersediaan infrastruktur dan teknologi yang sesuai dan kompetitif; Kelembagaan yang mendukung pengembangan ekonomi kreatif. ${ }^{5}$ Berikut survei yang dilakukan oleh Bank Indonesia terhadap Industri Kreatif di Indonesia. ${ }^{6}$

Tabel 1.1 Pertumbuhan Produksi Industri Kreatif

${ }^{1}$ Dewi Asri Jayanto and Zainal Asikin, 'Kajian Yuridis Terhadap Merek Sebagai Jaminan Pada Lembaga Perbankan', 32.3 (2017), 508-18.

2 Liana E Susanti, 'Economic Law Creation Beautiful Global Indonesia', Bestuur, 7.1 (2019), 47-53 $<$ https://jurnal.uns.ac.id/bestuur/article/view/42701>.

${ }^{3}$ Khoirul Hidayah and Ulama Hanafiah, 'Kajian Hukum Islam Terhadap Hak Merek', Kajian Hukum Islam Terbadap Hak Merek, 6.1 (2014), 1-9.

${ }^{4}$ Luh Inggita Dharmapatni, 'Hak Cipta Sebagai Suatu Objek Jaminan Fidusia', Lex Journal: Kajian Hukum \& Keadilan, $2.2(2018)<$ https://doi.org/10.25139/lex.v2i2.1412>.

${ }^{5}$ http://www.tempo.co/read/news/2014/06/18/174586251/Tujuh-Isu-Strategis-dalam Ekonomi-Kreatif

${ }^{6}$ Iswi Hariyani, 'Penjaminan Hak Cipta Melalui Skema Gadai Dan Fidusia', Jurnal Hukum IUS QULA IUSTUM, 23.2 (2016), 294-319<https://doi.org/10.20885/iustum.vol23.iss2.art7>. 


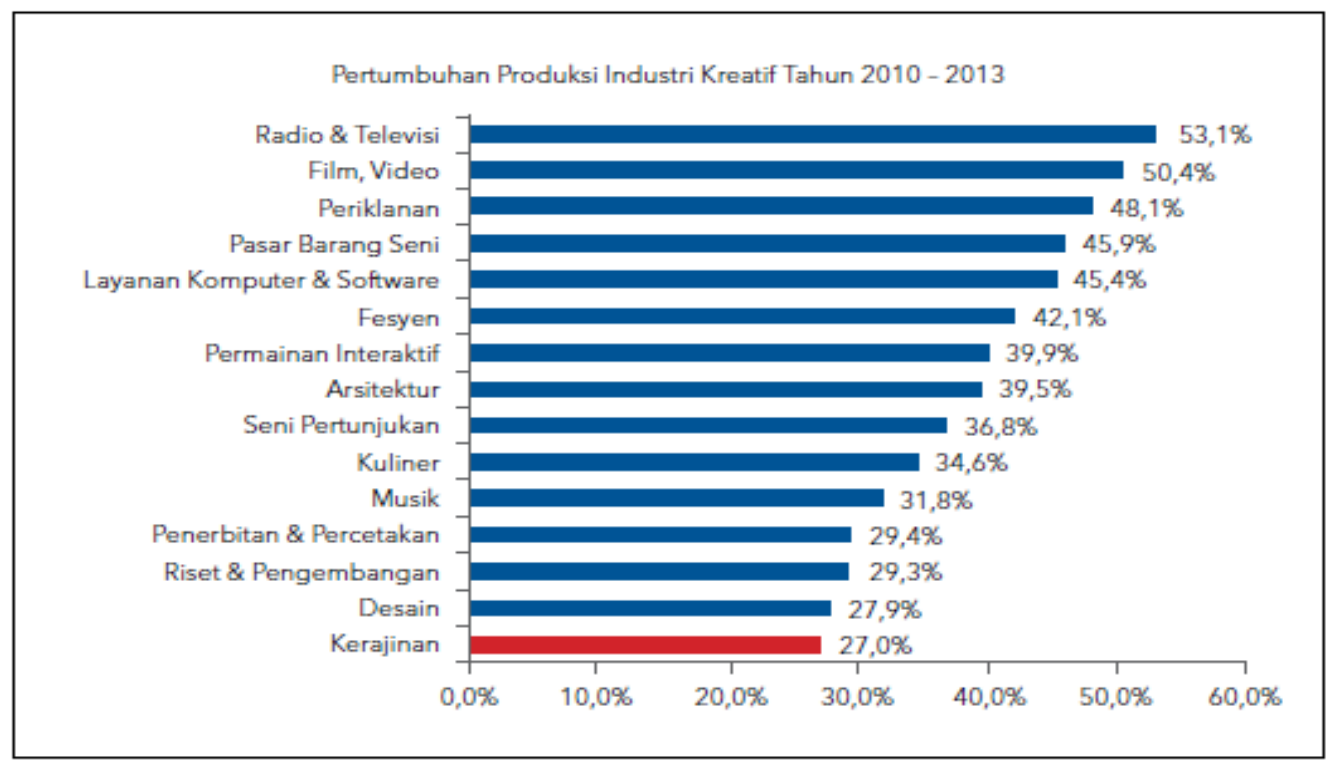

Sumber: Kemenparekraf, diolah tim Bank Dunia

Dari tabel 1.1 pertumbuhan produksi industri kreatif dari tahun 2010-2013 diatas menunjukkan industri kreatif kerajnan berada pada posisi paling terendah dengan yaitu sebesar $27,0 \%$.

Tabel 1.2 Pertumbuhan Jumlah Usaha Industri Kreatif

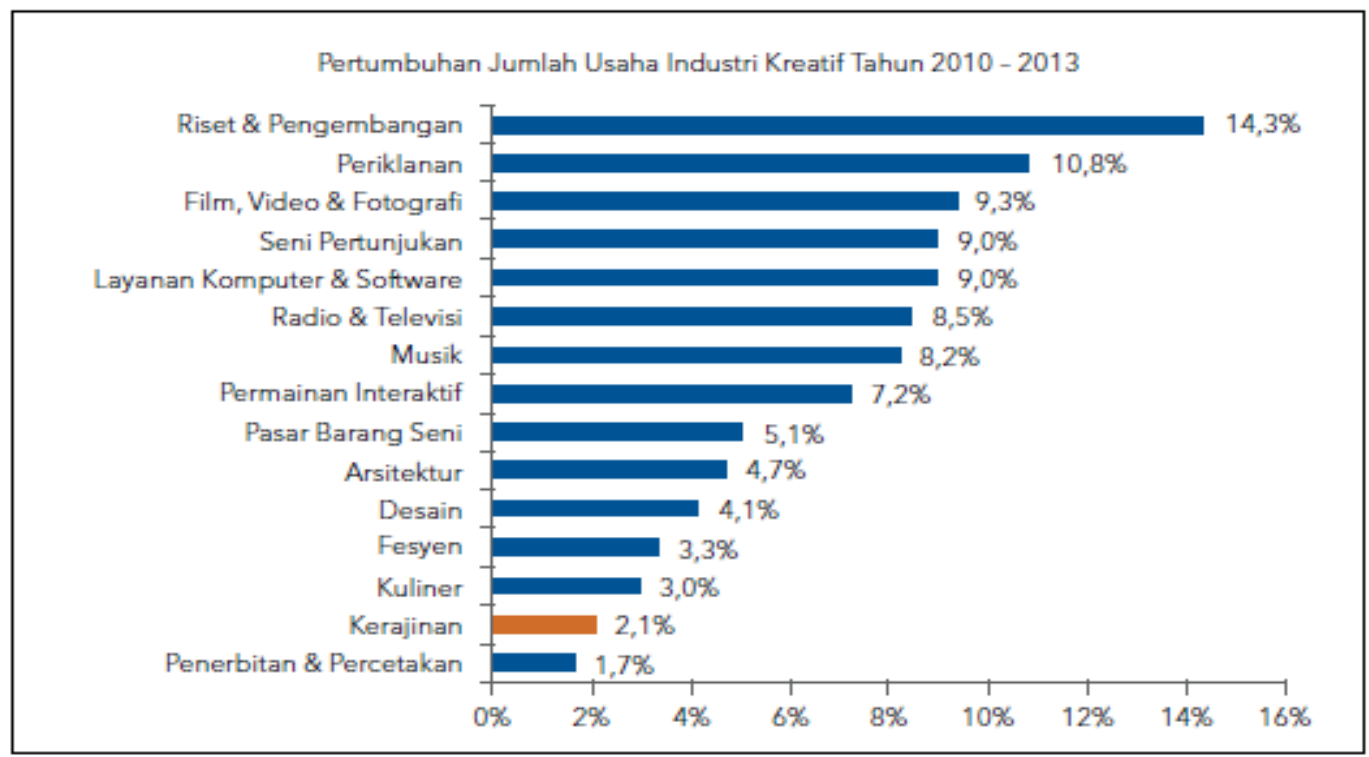

Sumber: Kemenparekraf, diolah oleh tim Bank Dunia

Dari bagan diatas kedua indikator pertumbuhan produksi dan jumlah usaha industri kreatif kerajinan mengindikasikan adanya kendala yang menyebabkan sektor ini tumbuh dengan tingkat yang rendah. Kajian yang dilakukan oleh Kementerian Perindustrian mengungkapkan bahwa untuk dapat berkembang dengan optimal industri kerajinan memerlukan beberapa faktor pendukung. ${ }^{7}$ Secara spesifik World Economic Forum dalam laporannya menyampaikan bahwa kualitas infrastruktur, kondisi pasar yang efisien, produktivitas tenaga kerja yang tinggi, regulasi/birokrasi pemerintah, dan kualitas akses pembiayaan yang baik adalah beberapa faktor pendukung yang sangat diperlukan

${ }^{7}$ Ahmad Dwi Nuryanto, 'Problem Penyidikan Tindak Pidana Pencucian Uang Yang Berasal Dari Predicate Crime Perbankan', Bestuur, 7.1 (2019), 54 <https://doi.org/10.20961/bestuur.v7i1.43437>. 
untuk dapat mengembangkan sektor industri, khususnya sektor industri kerajinan, secara optimal dan berdaya saing. Kementerian Perdagangan dalam buku Rencana Pengembangan Ekonomi Kreatif 2009-2015 juga mengidentifikasi terbatasnya akses pelaku-pelaku usaha di sektor ekonomi kreatif terhadap sumber-sumber pembiayaan dari lembaga keuangan formal sebagai salah satu dari lima isu utama dalam pengembangan industri kreatif di Indonesia. ${ }^{8}$

Mengamati hasil-hasil studi mengenai industri kreatif yang telah dilakukan hingga saat ini terdapat satu isu penting dalam pengembangan industri kreatif di Indonesia yang masih luput dari pembahasan secara mendalam, yaitu pembahasan mengenai peningkatan akses pelaku usaha di sektor ekonomi kreatif terhadap pembiayaan dari lembaga-lembaga keuangan formal. Pembahasan mengenai akses pembiayaan kepada industri kreatif menjadi penting mengingat pembiayaan merupakan salah satu aspek yang paling dibutuhkan oleh pemain dalam industri kreatif untuk mengembangkan bisnis dan meningkatkan daya saing produk mereka.

Terkait dengan hambatan teknis yang dihadapi oleh pelaku usaha di dalam mengakses pembiayaan, survei dari bank Indonesia menemukan bahwa ketidakmampuan untuk memenuhi jumlah jaminan yang diminta oleh lembaga keuangan (40\%) serta tingginya suku bunga pinjaman $(37 \%)$, merupakan hambatan utama pelaku usaha untuk mengakses pembiayaan eksternal. ${ }^{10}$

Tabel 1.3 Hambatan dalam Mengakses Sumber Pembiayaan Formal

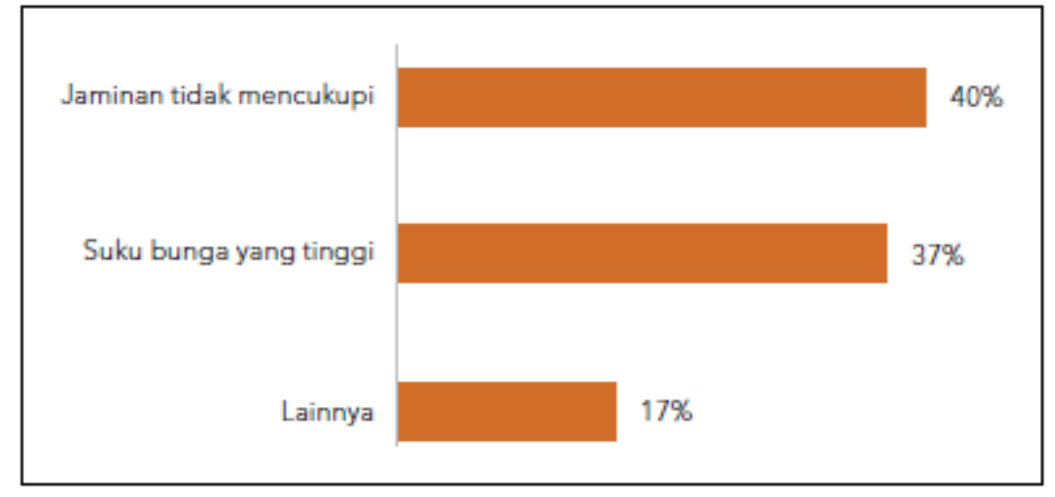

Sumber: Hasil survei Tim Bank Dunia (2014)

Lebih lanjut bank Indonesia juga mengungkapkan, Aset yang umumnya dimiliki secara pribadi oleh pengrajin UMKM adalah tanah (36\%), bangunan (32\%), kendaraan bermotor (24\%) dan mesin atau peralatan (8\%). Beberapa pelaku usaha industri kerajinan yang telah memiliki jaminan pun ternyata masih menghadapi kendala. Hal tersebut berupa nilai jaminan yang dimiliki tidak memadai untuk mendapatkan nilai pinjaman yang dibutuhkan, dokumen-dokumen kepemilikan jaminan tidak memenuhi syarat lembaga keuangan atau tidak \lengkap, serta jaminan yang dimiliki merupakan milik keluarga yang tidak dapat diagunkan dengan alasan pribadi. Di sisi lain, jaminan dalam bentuk Purchase Order (PO) ataupun Letter of Credit (LC) tidak umum digunakan, antara lain karena pengusaha menganggap prosedurnya terlalu rumit dan belum sepenuhnya bisa diterima oleh bank. ${ }^{11}$

\footnotetext{
${ }^{8}$ Hidayah and Hanafiah.

${ }^{9}$ Made Bagus and Satria Yudistira, 'MEREK SEBAGAI JAMINAN FIDUSIA DALAM PROSES PENGAJUAN KREDIT DI PERBANKAN BERDASARKAN UNDANG-UNDANG NOMOR 20 TAHUN 2016 Magister Hukum Udayana $\bullet, 20,2017,310-22$.

${ }^{10}$ Merek Pada and Bank Syariah, 'Usanti, Analisis Pembebanan Gadai Atas Sertifikat Merek Di Bank Syariah 413', 413-29.

${ }^{11}$ Dharmapatni. 
Dalam penelitian Asti Wulan dkk tentang perlindungan produk usaha mikro kecil dan menengah terkait hak kekayaan intelektual dalam masyarakat ekonomi asean. ${ }^{12}$ Hasil penelitian perlu adanya perlindungan produk UMKM dengan cara pendaftaran Hak Kekayaan Intlektual untuk menjaga tingkat orisinalitas produk menghadapi persaingan bebas. Hal ini diharapkan juga bisa diterapkan dalam industri kreatif dimana peran penting HKI menjaga stock of knowledge dan ide dari para pelaku industri kreatif yang ada di indonesia. ${ }^{13}$

Lebih lanjut HKI ini bisa digunakan sebagai aspek jaminan dalam melakukan permodalan di lembaga keuangan. Seperti dalam jurnal Junaidi Akhmad dan Joni Muhammad, 2011. "Pemanfaatan Sertifikat HKI sebagai Collateral Kredit". Jurnal Smecda, Volume 6 September : 124-141. Hak Kekayaan Intelektual (HKI) di negara-negara maju telah diperluas pemanfaatannya sebagai collateral untuk mendapatkan kredit atau pembiayaan dari lembaga keuangan. Nilai ekonomi HKI dapat ditentukan dengan menghitung misalnya nilai pasar, biaya pembuatan/reproduksi, biaya penggantian penyusutan, nilai likuidasi, dan nilai asuransi. Permasalahan yang dihadapi di Indonesia adalah belum tersedianya suatu ketentuan tentang penggunaan HKI sebagai collateral dalam sistem penyaluran kredit perbankan. ${ }^{14}$

Berdasarkan permasalahan diatas peneliti menerapkan konsep untuk membantu industri kreatif batik pekalongan dengan judul "Hak Merek sebagai jaminan untuk permodalan industri kreatif kerajinan batik". Tulisan ini akan membahas dan mempertanyakan 3 (tiga) hal, yakni: Hak Merek termasuk benda, Bagaimana konsep penilaian hak merek, dan Bagaimana mekanisme hak merek sebagai jaminan Gadai.

\section{PEMBAHASAN}

\section{Konsep Hak Merek Sebagai harta benda}

Hukum normatif di Indonesia tidak ada terminologi hak merek sebagai harta, akan tetapi sebagai benda. Pada KUHPerdata dijabarkan bahwa yang dimaksud benda menurut bentuknya yaitu benda materiil atau berwujud dan benda immateriil atau tidak berwujud. ${ }^{15}$

Pemahaman hak merek sebagai hak kebendaan berangkat dari ketentuan pasal 499 KUHPerdata yang berbunyi : "Kebendaan ialah tiap-tiap barang dan tiap-tiap hak, yang dapat dikuasai oleh hak milik." jika kita telaah dari pasal diatas sangat jelas yang disebut kebendaan itu mencakup dua hal, yakni benda sebagai barang (yang berwujud/materi) dan benda sebagai hak (yang tidak berwujud/immateri). Hak merek sebagai hak ekslusif pada hakekatnya merupakan hak hukum, oleh karena hak hukum maka hak merek dapat diklasifikasi menjadi hak kebendaan yang sifatnya tidak berwujud, maka hak merek berpeluang untuk dapat dialihkan dan diperalihkan kepada pihak lain. Peralihan itu sendiri dalam bentuk hak ekonomi. Sehingga hak merek dapat dikatakan sebagai benda, wujud dari kebendaannya bisa berupa sertifikat kepemilikan hak merek yang telah di daftarkan di Direktorat Jenderal Hak Kekayaan Intelektual (Ditjen HKI). ${ }^{16}$

\section{Penilaian Nilai Ekonomis dari Hak Merek}

Penilaian nilai ekonomis dari hak merek perlu dilakukan untuk menunjukkan bahwa hak merek dapat diakui secara sebagai salah satu jenis harta benda yang bernilai.Benda itu dapat dikatakan

12 Asti Wulan dkk, "Perlindungan Produk Usaha Mikro Kecil dan Menengab Terkait Hak Kekayaan Intelektual dalam Menghadapi Masyarakat Ekonomi Asean”, Diponegoro Law Jurnal, Volume 5, No 3 Tahun 2016, hlm 10.

${ }^{13}$ I.G.A.K. Rachmi Handayani, Lego Karjoko, and Abdul Kadir Jaelani, 'Model Pelaksanaan Putusan Mahkamah Konstitusi Yang Eksekutabilitas Dalam Pengujian Peraturan Perundang-Undangan Di Indonesia', Bestuur, 7.1 (2019), 36-46 <https://jurnal.uns.ac.id/bestuur/article/view/42700>.

${ }^{14}$ Muhammad Yuris Azmi, 'Nomor 28 Tahun 2014 Tentang Hak Cipta Dan Undang-Undang Tentang Jaminan Fidusia', Universitas Sebelas Maret, IV.1 (2016), 97-106.

${ }^{15}$ Febry Wulandari and W Waluyo, 'Efektivitas Pemanfaatan Dana Bagi Hasil Cukai Hasil Tembakau Dalam Bidang Kesehatan Di Kota Surakarta Tahun 2018', Jurnal Bestuur, 7.1 (2019).

16 Sri Mulyani, 'Realitas Pengakuan Hukum Terhadap Hak Atas Hak Atas Merek Sebagai Jaminan Fidusia Pada Praktik Perbankan', Jurnal Hukum Dan Dinamika Masyarakat, 11.2 (2014), 139. 
bernilai apabila memenuhi beberapa syarat yaitu harus memiliki daya guna, ketersediaannya terbatas dan kepemilikannya dapat dipindahkan. Dalam konteks ini hak merek memenuhi semua unsur dan syarat-syarat untuk dapat dikatakan sebagai benda yang memiliki nilai ekonomi. Perlu di pertegas bahwa nilai ekonomi pada hak merek merupakan kekayaan bagi pemiliknya yang memberikan hak bagi pemiliknya untuk dapat memanfaatkan serta menikmati hasil yang diberi oleh kekayaan intelektual tersebut. Untuk itu diperlukan suatu bentuk penilaian sebagai dasar untuk menetapkan nilai hak cipta sebagai suatu aset yang dapat dimanfaatkan. Penilaian berperan penting dalam menentukan nilai ekonomi aset dan potensi harta kekayaan yang dimiliki. ${ }^{17}$

Menurut Ahmad Ramli penilaian aset hak merek (HKI) dapat dilihat dari dua sisi. Pertama, Aset nyata dari aset hak merek dan bukan hanya pada harga, dan kedua, Perkiraan penilaian didasari oleh seberapa besar modal dapat diperoleh dari aset hak merek. Dari penilaian hak merek ini akan memberikan potensi penilaian yang ditujukan kepada: 1) Seberapa besar aset hak merek terlindungi secara hukum yang berlaku, 2) Status HKI yang dimiliki, misalnya apakah terdapat proses litimigasi, somasi, atau pembatalan hak, dan 3) Potensi yang mendasari aset HKI tentang besar kecilnya kompetitor yang mempengaruhi aset. ${ }^{18}$

Berdasarkan hal diatas ada 3 metode yang lazim dan banyak digunakan dalam menilai HKI (termasuk hak merek) dapat dilihat pada gambar 1.1 berikut ini:

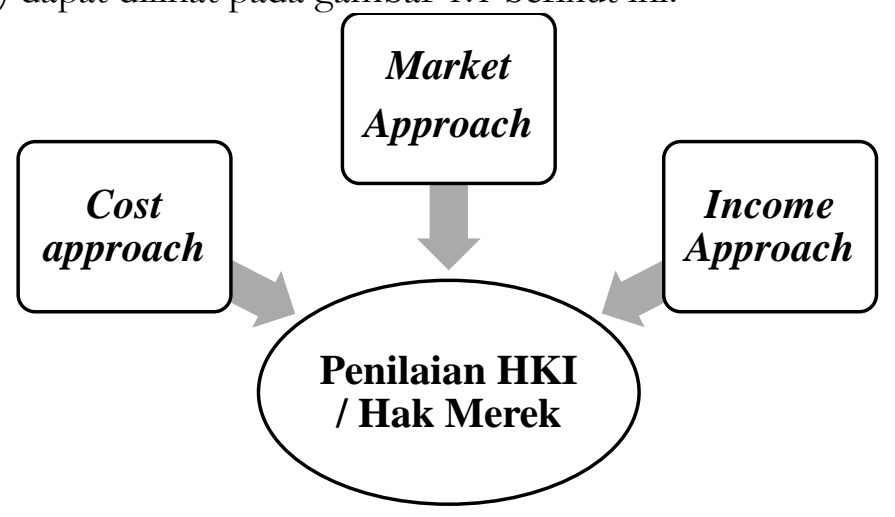

Sumber: Indra Rahmatullah ${ }^{19}$

Gambar 1.1 Penliaian HKI/ Hak Merek

Penilaian HKI atau Hak Merek berdasarkan 3 tiga pendekatan dapat dijelaskan sebagai berikut:

\section{a. Cost approach (Pendekatan harga)}

Pendekatan ini digunakan untuk menentukan indikasi nilai aset dengan memperkirakan harga reproduksi (reproduction) atau harga subtitusi (replacement) aset yang dikurangi nilai susut karena fisik, menekankan nilai aset tak berwujud berdasarkan prinsip ekonomi subtitusi yang sepadan dengan biaya yang akan dikeluarkan sebagai pengganti yang sebanding. Biaya tersebut termasuk biaya material atau bahan dasar dan biaya pekerja. Perkiraan-perkiraan biaya tersebut sudah diperaktikkan di inggris dalam kasus hak lisensi di industri medis dan farmasi dengan memberikan biaya untuk penelitian dan pengembangan paten serta untuk biaya promosi.

\section{b. Market Approach (Pendekatan pasar)}

Pendekatan ini menggunakan kerangka kerja sistematis untuk menentukan perkiraan nilai aset tak berwujud berdasarkan analisis penjualan aktual dan/atau transaksi lisensi berwujud yang

${ }^{17}$ Djoko Hadi Santoso and Agung - Sujatmiko, 'Royalti Hak Cipta Sebagai Obyek Jaminan Fidusia', Masalah-Masalah Hukum, 46.3 (2018), 198 <https://doi.org/10.14710/mmh.46.3.2017.198-204>.

${ }^{18}$ Hariyani.

${ }^{19}$ Indra Rahmatullah, Aset Hak Kekayaan Intelektual Sebagai Jaminan dalam Perbankan, (Yogyakarta : Depublish 2016), hlm 142-144. 
sebanding dengan objeknya dalam sebuah pasar yang kompetitif. Perbandingan dilakukan atas dasar kondisi permintaan dan penawaran dalam titik ekuilibrium.

Pendekatan ini terdiri dari 2 jenis yaitu, Comparable Market Value dan Comparable Royalty Value. Comparable Market V alue ditentukan dengan merujuk pada perbandingan harga dari jenis-jenis HKI yang ada dalam transaksi. Sedangkan Comparable Royalty Value ditentukan dengan merujuk pada perbandingan rata-rata royalti HKI.

\section{c. Income Approach (pendekatan pendapatan)}

Pendekatan ini menggunakan kerangka kerja dalam menentukan nilai dari aset dengan mengkalkulasikan nilai yang akan datang. Nilai dari masa yang akan datang tersebut berasal dari mekanisme penggunaan lisensi dan rata-rata royalti yang didapat. Terdapat 3 hal yang harus dipertimbangkan melalui penggunaan ini yaitu :

1. Mengidentifikasikan potensi pendapatan yang didapat dimasa yang akan datang dari jenis atau layanan HKI

2. Pengukuran jangka waktu pendapatan

3. Pengukuran terhadap risiko yang berasal dari pendapatan

Sehingga inti dari pendekatan ini adalah menetukan nilai dari masa yang akan datang berasal dari arus kas cash flow.

\section{Mekanisme Hak Cipta sebagai Jaminan di Pembiayaan Gadai}

Gadai sebagai model pembiayaan dilakukan dengan cara menjaminkan barang berharga untuk memperoleh utang yang dapat digunakan untuk pelunasan utang tersebut apabila utang tersebut tidak dilunasi dalam jangka waktu yang ditentukan. Pembiayaan gadai merupakan cara untuk memberikan pembiayaan kepada masyarakat. Mekanisme gadai yaitu anggota masyarakat yang memerlukan pinjaman menjaminkan hartanya kepada pegadaian, sebagai jaminan. Lembaga pegadaian dalam menyalurkan kredit menuntut barang agunan yang dipegang sebagai jaminan atas kredit tersebut. Barang agunan yang digunakan dalam perjanjian gadai. Dalam hal ini sertifikat hak merek akan digunakan sebagai agunan jaminan gadai. ${ }^{20}$

Menurut Iswi Hariyani, agunan jaminan hak cipta pada UUHC No. 28 Tahun 2014 hanya mengatur penjaminan hak cipta melalui skema Fidusia, sehingga diperlukan revisi UU tersebut agar penjaminan hak merek juga bisa dilakukan melalui skema gadai. ${ }^{21}$ Revisi ini dilakukan karena penjaminan jaminan fidusia tentunya berbeda dengan gadai. Perjanjian jaminan gadai tidak wajib menggunakan akta notaris sebab obyek jaminannya berada di tangan pihak kreditor (pegadaian). Sedangkan perjanjian jaminan fidusia harus dibuat menggunakan akta notaris dan harus didaftarkan ke Kantor Pendaftaran Fidusia pada Kementerian Hukum dan HAM. ${ }^{22}$

Pengaturan fidusia dibuat lebih ketat dibandingkan gadai, sebab obyek jaminan fidusia berada di tangan debitor (nasabah) dengan status hak pakai. Jika kelak pihak debitor pemberi gadai ingkar janji (wanprestasi), maka pihak kreditor (pegadaian) dapat langsung mengeksekusi obyek jaminan melalui mekanisme Parate Eksekusi atau tanpa harus minta ijin Ketua Pengadilan Negeri setempat. ${ }^{23}$

Pengalihan hak merek tidak berdampak pada hak moral yang dimiliki pencipta. Meskipun karya cipta yang digadaikan telah berpindah tangan berkali-kali, namun nama pencipta tetap harus dicantumkan sebab pencipta memiliki hak moral yang berlaku selamanya. Di sisi lain, pengalihan hak merek bisa berdampak pada hilangnya hak ekonomi yang dimiliki pencipta. Pencipta yang telah menjual karya ciptanya ke pihak lain tidak dapat membuat perjanjian lisensi (waralaba). ${ }^{24}$ Teknis

${ }^{20}$ Nur Adi Kumaladewi, 'Eksekusi Kendaraan Bermotor Sebagai Jaminan Fidusia Yang Berada Pada Pihak Ketiga', Jurnal Repertorium, II.2 (2015), 60-77.

${ }^{21}$ Kumaladewi.

22 Azmi.

23 Santoso and Sujatmiko.

${ }^{24}$ Iswi Hariyani, Penjaminan Hak. Cipta,.. hlm. 308. 
operasional dalam pembiayaan gadai dengan menggunakan agunan jaminan hak cipta dapat diilustrasikan pada gambar 1.2 sebagai berikut:

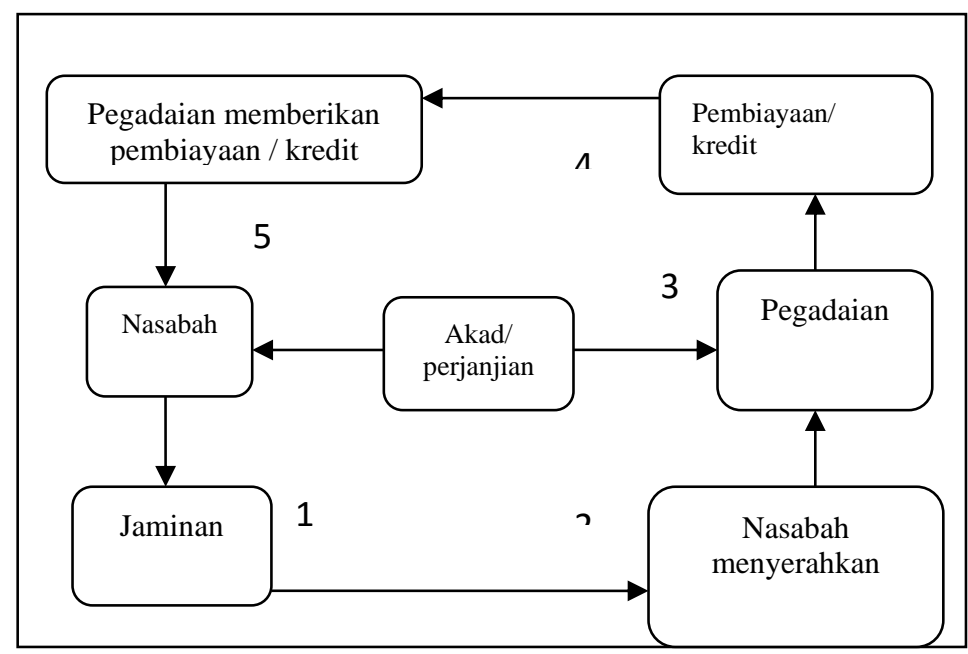

Gambar 1.2 Teknis Operasional dalam Lembaga Pembiayaan Gadai

Keterangan :

1. Nasabah mengisis formulir permintaan gadai dengan membawa agunan jaminan sertifikat hak merek

2. Nasabah menyerahkan formulir permintaan gadai yang dilampiri dengan foto copy identitas serta barang jaminan (sertifikat hak merek) ke loket

3. Petugas pegadaian menaksir (gadai atau hak cipta) agunan yang sudah diserahkan

4. Besarnya pinjaman adalah sebesar $90 \%$ dari taksir agunan

5. Apabila disepakati besarnya pinjaman, nasabah menandatangani akad dan menerima uang pinjaman.

Melihat dari teknis operasional dalam pembiayaan gadai dengan menggunakan agunan jaminan hak merek di atas, sebenarnya tidak jauh berbeda dengan pembiayaan gadai pada umumnya. Tetapi pada bagian ketiga terdapat perbedaan. Penaksiran hak merek tentunya berbeda dengan agunan jaminan jenis lain yang biasa digunakan dipegadaian, agunan yang biasa dijumpai di pegadaian antara lain: semua barang yang bergerak dan tidak bergerak, emas, motor, tanah dan lain-lain. Oleh sebab itu agunan jaminan hak merek tidak bisa ditakar oleh penaksir gadai. Pengukuran atau penaksiran agunan jaminan hak merek sangatlah penting karena berkaitan dengan besar kecilnya pinjaman yang diberikan kepada nasabah. Penaksiran agunan ini dapat mengikuti penilaian yang telah dijelaskan sebelumnya berupa: cost approach, market approach dan income approach. ${ }^{25}$

\section{PENUTUP}

Hasil penelitian bahwa Hak merek dapat digunakan untuk menjadi jaminan dalam skema gadai. yaitu dengan tahapan-tahapan sebagai berikut: pertama, hak merek diakui sebagai harta benda yang dapat dialihkan, karena yang akan digunakan sebagai jaminan adalah harta benda. Kedua, penliaian hak merek dapat dilakukan melalui 3 tiga pendekatan yaitu cost approach, market approach dan income approach. Dan ketiga, mekanisme penggunaan hak merek sebagai jaminan gadai dengan alur dan skema gadai yang dapat diterapkan di lembaga pegadaian. Hak merek sebagai jaminan gadai merupakan wacana yang belum ada prakteknya di Indonesia, oleh sebab itu hendaknya mendapat perhatian khusus dari pemerintah, mengingat peranan hak merek dalam kehidupan merupakan suatu upaya untuk memotivasi individu untuk berusaha mengembangkan kreatifitasnya dan untuk mengembangkan ilmu pengetahuan yang dimilikinya. Hak merek sebagai jaminan bisa menjadi

25 Wulandari and Waluyo. 
alternatif aspek permodalan yang selama ini sangat dibutuhkan oleh UMKM industri batik, sehingga perananan penting pemerintah dalam membuat regulasi dan peraturan terkait pemanfaatan hak merek.

\section{REFERENCES}

Azmi, Muhammad Yuris, 'Nomor 28 Tahun 2014 Tentang Hak Cipta Dan Undang-Undang Tentang Jaminan Fidusia', Universitas Sebelas Maret, IV.1 (2016), 97-106

Bagus, Made, and Satria Yudistira, 'Merek Sebagai Jaminan Fidusia Dalam Proses Pengajuan Kredit

Di Perbankan Berdasarkan Undang-Undang Nomor 20 Tahun 2016 Magister Hukum

Udayana •', 20, 2017, 310-22

Dharmapatni, Luh Inggita, 'Hak Cipta Sebagai Suatu Objek Jaminan Fidusia', Lex Journal: Kajian Hukum \& Keadilan, 2.2 (2018) <https://doi.org/10.25139/lex.v2i2.1412>

Handayani, I.G.A.K. Rachmi, Lego Karjoko, and Abdul Kadir Jaelani, 'Model Pelaksanaan Putusan Mahkamah Konstitusi Yang Eksekutabilitas Dalam Pengujian Peraturan Perundang$\begin{array}{lllll}\text { Undangan Di Indonesia', Bestuur, } 7.1 \quad \text { (2019), } & \text { 36-46 }\end{array}$ $<$ https://jurnal.uns.ac.id/bestuur/article/view/42700>

Hariyani, Iswi, 'Penjaminan Hak Cipta Melalui Skema Gadai Dan Fidusia', Jurnal Hukum IUS QUIA IUSTUM, 23.2 (2016), 294-319 <https://doi.org/10.20885/iustum.vol23.iss2.art7>

Hidayah, Khoirul, and Ulama Hanafiah, 'Kajian Hukum Islam Terhadap Hak Merek', Kajian Hukum Islam Terbadap Hak Merek, 6.1 (2014), 1-9

Jayanto, Dewi Asri, and Zainal Asikin, 'Kajian Yuridis Terhadap Merek Sebagai Jaminan Pada Lembaga Perbankan', 32.3 (2017), 508-18

Kumaladewi, Nur Adi, 'Eksekusi Kendaraan Bermotor Sebagai Jaminan Fidusia Yang Berada Pada Pihak Ketiga', Jurnal Repertorium, II.2 (2015), 60-77

Mulyani, Sri, 'Realitas Pengakuan Hukum Terhadap Hak Atas Hak Atas Merek Sebagai Jaminan Fidusia Pada Praktik Perbankan', Jurnal Hukum Dan Dinamika Masyarakat, 11.2 (2014), 139

Nuryanto, Ahmad Dwi, 'Problem Penyidikan Tindak Pidana Pencucian Uang Yang Berasal Dari

$\begin{array}{llllll}\text { Predicate } \quad \text { Crime } \quad \text { Perbankan', Bestuur, } & 7.1 & \text { (2019), }\end{array}$ <https://doi.org/10.20961/bestuur.v7i1.43437>

Pada, Merek, and Bank Syariah, 'Usanti, Analisis Pembebanan Gadai Atas Sertifikat Merek Di Bank Syariah 413', 413-29

Santoso, Djoko Hadi, and Agung - Sujatmiko, 'Royalti Hak Cipta Sebagai Obyek Jaminan Fidusia', Masalah-Masalab Hukum, 46.3 (2018), 198 <https://doi.org/10.14710/mmh.46.3.2017.198204>

Susanti, Liana E, 'Economic Law Creation Beautiful Global Indonesia', Bestuur, 7.1 (2019), 47-53 $<$ https://jurnal.uns.ac.id/bestuur/article/view/42701>

Wulandari, Febry, and W Waluyo, 'Efektivitas Pemanfaatan Dana Bagi Hasil Cukai Hasil Tembakau Dalam Bidang Kesehatan Di Kota Surakarta Tahun 2018', Jurnal Bestuur, 7.1 (2019) 